\title{
Tsangnyön Heruka
}

\section{Tibet under 1400- och 1500-talet}

Tsangnyön och hans lärjungar levde under 1400- och 1500-talet, en dynamisk, kreativ och turbulent period av Tibets historia som vi vet förhållandevis lite om. ${ }^{62}$ Buddhismen i Tibet genomgick en omfattande institutionalisering under denna tid. Klostren blev fler, större och mer välorganiserade, och de olika buddhistiska traditionerna - sakya, kagyu, gelug, jonang, bodong och nyingma - utvecklades, institutionaliserades och avgränsades från varandra.

Det var under denna tidsperiod som många av de mest karaktäristiska dragen i den tibetanska buddhismen, såsom gelugpaskolan och Dalai lama-institutionen, växte fram. Under 1400- och 1500talet kom också det för Tibet unika systemet med reinkarnerade lamasuccessioner att bli alltmer allmänt förekommande och viktigt. Den första läraren som medvetet återföddes på detta sätt anses ha varit den andra Karmapa, Karma Pakshi (1204-1283), som sades vara en reinkarnation av Dusum Khyenpa (1110-1193), den första Karmapa. Efter hand började andra traditioner ta efter detta successionssystem, och under 1400- och 1500-talet började succession genom reinkarnation alltmer ersätta andra successionsformer, som till exempel traditioner där lärarna var gifta och lät sina barn föra vidare traditionen. Inom gelugpaskolan, som grundades av lärjungar till Tsongkhapa, uppstod en reinkarnationslinje som så småningom skulle få stort inflytande i Tibet och annorstädes: Dalai lamorna. När Tsangnyön och hans lärjungar levde hade dock ännu inte lärarna i denna inkarnationslinje fått sin mongoliska titel - dalai lama - och de hade inte heller fått någon politisk maktposition..$^{63}$

1400- och 1500-talet var på många sätt kagyutraditionens guld- 
ålder; karmakagyu, drukpakagyu, drikungkagyu och andra grenar inom skolan hade stort inflytande och många anhängare. Det faktum att Tibets mäktigaste lamor under denna tidsperiod - Karmapa- och Shamarpainkarnationerna - tillhörde karmakagyuskolan vittnar om att just denna skola hade en särskilt framträdande ställning. Samtidigt som kagyuskolan blomstrade växte den nya gelugpaskolan snabbt och en mängd stora gelugpakloster byggdes. Inom gelugpaskolan framhölls vikten av gradvis träning längs den buddhistiska vägen innan mer avancerade tantriska utövningar appliceras. Det var den lärda munken, snarare än den tantriska siddhan, som lyftes fram som ett ideal. De mest lärda munkarna inom gelugpa- och sakyaskolorna erhöll geshe-titlar. Tsangnyön och hans lärjungar hamnade ofta i dispyter med dessa geshes angående var, när och hur de mer avancerade tantriska övningarna skulle utövas.

På det politiska planet var Tibet splittrat under denna tid, men det hade inte att göra med inflytande från främmande makter. Den kinesiska Mingdynastin (1368-1644) var inte direkt inblandad i den tibetanska politiken, och mongolerna, som tidigare hade styrt över Tibet, var försvagade och splittrade och därför oförmögna att kontrollera landet. ${ }^{64}$ Eftersom det inte fanns någon tibetansk ledare som var kapabel att styra över hela det väldiga område där den tibetanska kulturen, språket och religionen hade en dominerande ställning, styrde olika härskare över olika delar av Tibet. Dessa härskare var ofta inblandade i konflikter och ibland i regelrätta krig med varandra. Tibets mäktigaste man under denna tidsperiod var Dönyö Dorje (1462-1512) som tillhörde en klan och ett distrikt vid namn Rinpung. Rinpungdynastin hade under 1400-talets senare hälft börjat ta makten i stora delar av Tibet och den tidigare så mäktiga Pagmodrudynastin som styrt centrala Tibet med omnejd i drygt hundra år var avsevärt försvagad.

De lokala härskarna var i allmänhet hängivna buddhister och stödde olika buddhistiska lärare och skolor. Rinpungdynastin hjälpte bland annat karmakagyuskolan, medan Pagmodrudynastin var nära allierade med gelugpaskolan. Det speciella förhållande som rådde mellan en politisk härskare och en religiös lärare samt dennes tradition kallas yon mchod, tibetanska för välgörare-lärare-relation. ${ }^{65}$ Härskaren gav frikostiga bidrag och beskydd till sin lärare och dennes 
tradition och kunde på så vis visa att han var en rättfärdig konung, vilket i gengäld legitimerade härskarens maktposition. Den intima relationen som rådde mellan politiska och religiösa intressen ledde inte sällan till att de buddhistiska skolorna drogs in i konflikter. Till exempel resulterade maktkampen mellan Rinpungdynastin och Pagmodrudynastin att förhållandet mellan karmakagyuskolan och gelugpaskolan efter hand blev alltmer spänt.

Den politiska splittringen hade dock inte endast negativa konsekvenser för buddhismen i Tibet. Ofta ledde den konkurrens som rådde mellan olika regioner, härskare och klaner till att dessa försökte överträffa varandra genom att stödja olika typer av buddhistiska aktiviteter, såsom boktryckning och tempelbyggen. På detta sätt kunde de stärka sin egen ställning och hävda att de var buddhistiska kungar som var värda folkets stöd. Detta medförde att kulturen i allmänhet och buddhismen i synnerhet blomstrade. Under 1400- och 1500-talet författades och trycktes många av Tibets mest betydelsefulla texter. Dessutom byggdes flera av de mest storslagna stūporna, templen och klostren. Vidare skapades en stor mängd enastående vackra statyer och målningar. Avsaknaden av en självklar central auktoritet återspeglade sig också i den mångfald av buddhistiska skolor, utövningsmetoder, texter och livsstilar som en buddhist hade tillgång till under denna tid.

Denna dynamiska situation kom att förändras i och med att mongolerna återigen blandade sig i Tibets politik. När Gushri Khan med militärt våld enade Tibet och såg till att hans lärare, den femte Dalai lama, Ngawang Lobsang Gyamtso (1617-1682), kom till makten år 1642, förändrades situationen i Tibet ${ }^{66}$ I och med detta blev den tibetanska buddhismen mindre kreativ och mer enhetlig. Gelugpaskolan övertog i samband med detta kagyuskolans framträdande särställning, och ett nytt politiskt system där Dalai lama och dennes regenter styrde i en sorts bodhisattvastyre inrättades. Detta styrelseskick kom att benämnas "Gandenpalatset" (tibetanskt uttal: Gandenpotrang, stavning: $d G a$ ' ldan pho brang) och fortlevde ända fram till 1959, då den nuvarande fjortonde Dalai lama flydde från Tibet och det kommunistiska Kina tog över makten. ${ }^{67}$ 


\section{Tsangnyön Herukas liv}

Det finns framför allt tre kategorier av källor som ger oss information om Tsangnyön Heruka. Till den första kategorin hör de texter som han själv författade och lät trycka. ${ }^{68} \mathrm{I}$ denna kategori ingår rituella texter av olika slag, en text om sånger, biografier om Milarepa och Marpa samt Milarepas sångsamling. ${ }^{69}$ Den mest välkända av dessa texter är utan tvekan biografin om Milarepa. ${ }^{70}$

Den andra källkategorin är de biografier om Tsangnyön som hans direkta lärjungar nedtecknade och tryckte efter hans bortgång. Det rör sig framför allt om tre relativt omfattande biografier. I två av dessa ingår även Tsangnyöns sånger. ${ }^{71}$ Sångerna gavs också ut separat, och med tanke på att sångerna förmodligen författades av Tsangnyön, men sammanställdes och trycktes av hans lärjungar, så utgör de på sätt och vis en mellankategori. ${ }^{72}$

Den tredje källkategorin utgörs av de bilder och statyer av Tsangnyön som hans lärjungar tillverkade. ${ }^{73}$ Med hjälp av dessa avbildningar får vi en uppfattning om hur Tsangnyön kan ha sett ut, om än i stiliserad och idealiserad form.

När Tsangnyöns lärjungar beskriver den galna yogin så framträder en bild av en fullkomnad mästare, en tibetansk motsvarighet till de indiska siddhorna, vars livsstil och meditationsmetoder Tsangnyön både förkunnade och utövade. Tsangnyön presenteras också som en reinkarnation av Tibets kanske största yogi, Milarepa, vars biografi, sånger och utövningsmetoder han ägnade en stor del av sitt liv åt att göra tillgängliga.

Nedanstående korta beskrivning av Tsangnyön Herukas liv är en återspegling av den bild som dessa källor ger oss. Det är framför allt ur den andra källkategorin, det vill säga de biografier som Tsangnyöns lärjungar sammanställde efter hans bortgång, som levnadsbeskrivningen är hämtad.

Det bör uppmärksammas att dessa "biografier" tillhör en speciell genre inom den tibetanska litteraturen och benämns rnam thar, "befrielseberättelser". ${ }^{74}$ Det finns en mycket stor mängd befrielseberättelser i Tibet, och Tsangnyön och hans lärjungar spelade en central roll för utvecklingen av denna litterära genre. Syftet med dylika levnadsskildringar är att redogöra för hur en buddhistisk mästare burit 
sig åt för att uppnå fullständig befrielse från tillvarons kretslopp. Den här typen av berättelser fokuserar på sådant som är av betydelse för en individs utveckling mot befrielse och buddhaskap, och lägger i allmänhet ingen större vikt vid händelser som inte är relaterade till detta. Därmed skiljer sig befrielseberättelser avsevärt från biografier i västerländsk litterär tradition. De liknar däremot helgonberättelser eller hagiografier i kristendomen.

Det finns en mängd återkommande teman i den här typen av livshistorier, såsom mirakulösa inslag, visioner och andliga upplevelser av olika slag. Rent generellt är det mycket svårt att särskilja historiska skeenden från lovprisande och idealiserande element i den här typen av litteratur. I detta avsnitt gör jag heller inga sådana anspråk. I stället har jag försökt att så troget som möjligt och kortfattat återberätta det som lärjungarna skriver om sin lama.

Enligt biografierna föddes Tsangnyön Heruka en fullmånedag under årets mest lyckosamma månad - sakadawa - samma månad som Buddha Śākyamuni föddes och blev upplyst ungefär två tusen år tidigare. Året var 1452 och Tsangnyön Herukas födelse ägde rum i en liten by vid namn Kharkha, en dryg mil norr om staden Gyantse i provinsen Tsang. Det sägs att en mängd mirakel inträffade när Tsangnyön föddes: jorden skakade, blommor regnade från himlen, vacker musik ljöd och behagliga dofter fyllde omgivningarna. Det sägs också att Tsangnyön kom ut ur sin moders mage sittande i meditationsställning och att han använde navelsträngen som meditationsbälte. ${ }^{75}$ Det första den nyfödda pojken gjorde när han lämnat sin mors mage var, enligt berättelsen, att sätta samman sina händer i bön och recitera ett mantra. Under hela sin barndom fortsatte Tsangnyön att uppträda på ett sätt som skiljde honom från andra barn i Kharkha. Han satt till exempel i meditationsposition i långa perioder och upprepade gärna mantror. Under sin barndoms lekar gav han sina lekkamrater rituella invigningar, tillverkade rituella offerkakor (torma) och så vidare.

Allt detta sammantaget visade att Tsangnyön inte var någon vanlig människa. Hans ovanliga uppträdande och mirakulösa födelse tydde på att han var en exceptionell individ som hade ägnat åtskilliga tidigare liv åt buddhistisk utövning. Det började ryktas om att Tsangnyön var en reinkarnation av en tidigare lama, kanske rentav en emanation av en buddha eller bodhisattva. Efter hand blev allt fler 
övertygade om att Tsangnyön var en reinkarnation av Milarepa. ${ }^{76}$ Milarepa hade valt att återfödas för att återupprätta den lära och de ideal som han förkunnat flera hundra år tidigare, men som var på väg att falla i glömska.

Biografierna beskriver hur Tsangnyön, när han var i sjuårsåldern, överväldigades av en oändligt stor medkänsla gentemot alla kännande varelser. Han bestämde sig för att till varje pris befria varelserna i tillvarons kretslopp från deras olika lidanden. Med denna motivation som grund avlade Tsangnyön novislöften. ${ }^{77}$ Som novismunk utmärkte han sig bland annat genom sin enastående förmåga att memorera buddhistiska texter och för sin exemplariska disciplin.

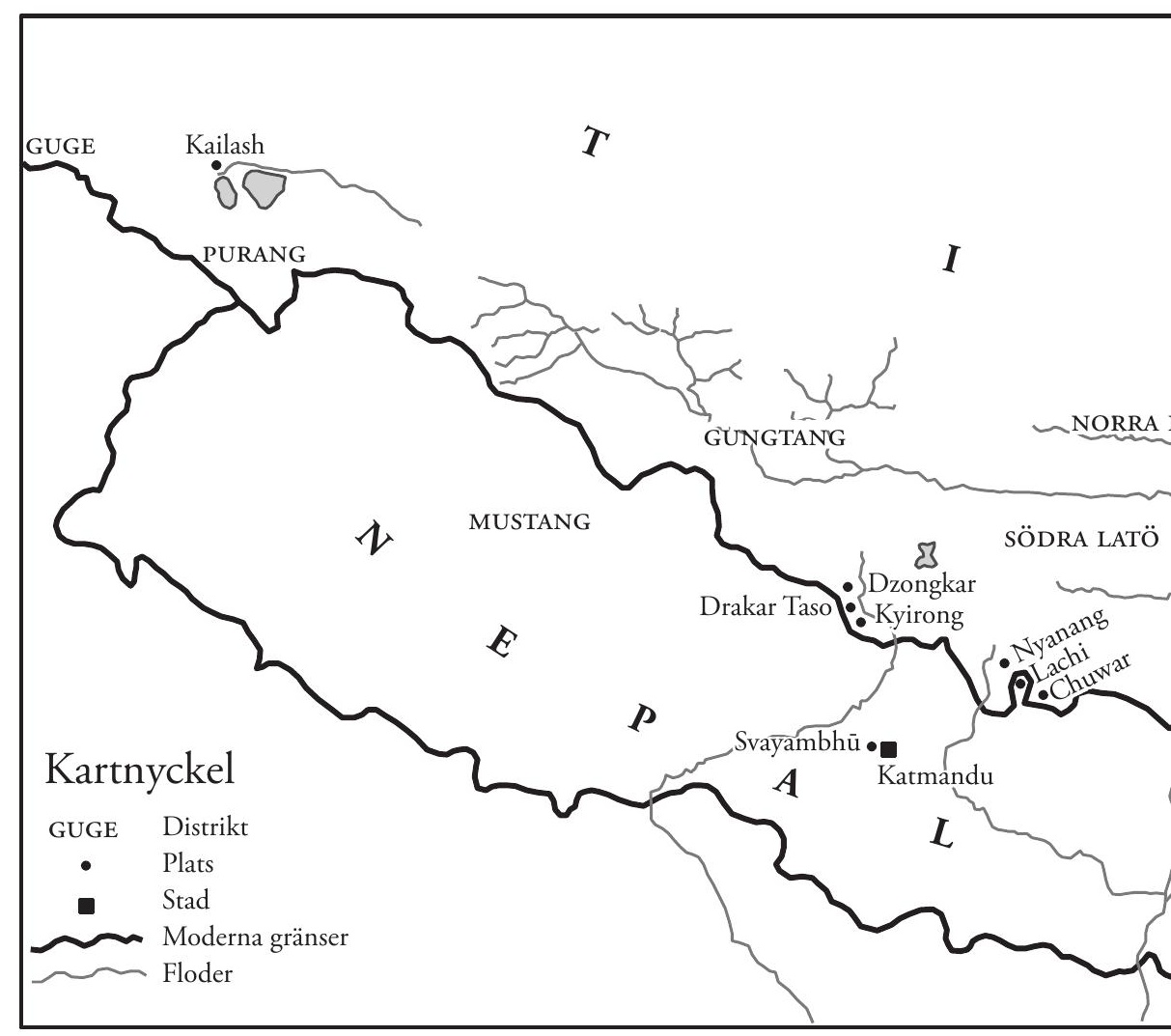

Bild 2. Karta över platser som var viktiga för Tsangnyön Heruka. 
När han vid ett tillfälle, tillsammans med åtta andra munkar, var inbjuden till en familj för att recitera den mest utförliga - hundratusen verser långa - versionen av Vishetens fulländning upptäckte familjen som bjudit in honom att han blundade medan han läste. ${ }^{78}$ Familjen som bjudit in munkarna misstänkte att Tsangnyön bara låtsades läsa. När de konfronterade den unga Tsangnyön med denna anklagelse så erbjöd han dem att granska honom. De andra munkarna slutade att recitera och med bindel för ögonen reciterade Tsangnyön ensam, medan de andra tittade i texten för att se om han verkligen läste korrekt. Det visade sig att Tsangnyön lyckats memorera hela denna omfattande text och exakt kunde återge varje stavelse. Efter denna

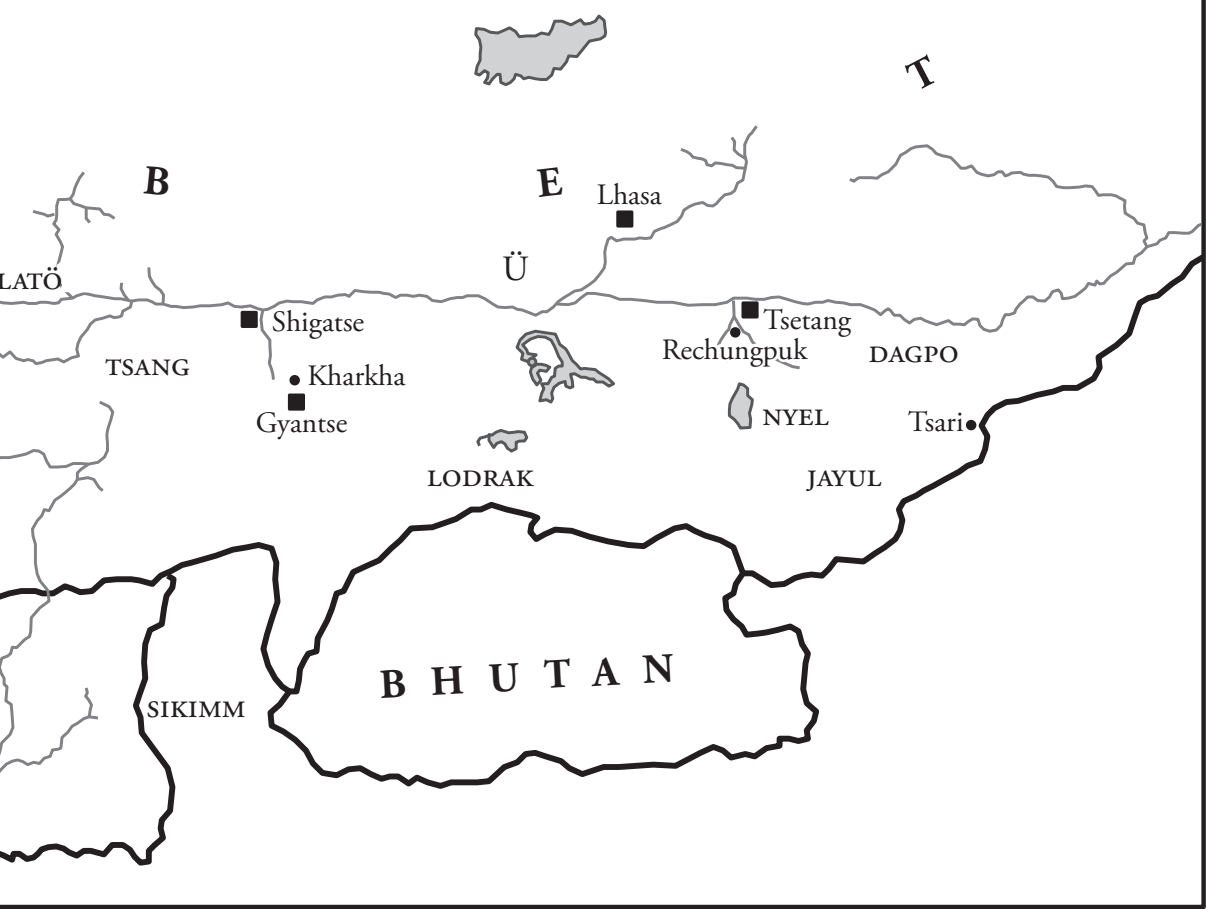


händelse blev Tsangnyön känd som munken som kan recitera den hundratusen verser långa versionen av Vishetens fulländning utantill.

Tsangnyön blev också omtalad för sin enastående förmåga att upprätthålla sin yttre disciplin på ett klanderfritt sätt. Det sägs att han som trettonåring hängde en påse med dödligt gift runt sin hals och lovade att svälja giftet om han någonsin skulle bryta något av sina klosterlöften. ”Om jag inte dör av giftet må då min skyddsgudomlighet döda mig", tillade han. ${ }^{79}$ Så fort begär uppstod i den unga munkens sinne rörde han vid sin giftpåse och då försvann begäret genast.

När Tsangnyön var i de tidiga tonåren fick han upprepade visioner av himmelska väsen som uppmanade honom att lämna sin trygga tillvaro hemma i Kharkha för att ägna sig åt meditation i avlägset belägna bergsområden. Hans mor tillät honom inte att följa dessa visionära uppmaningar, vilket ledde till att Tsangnyön rymde hemifrån. Han upptäcktes dock och fördes tillbaka hem. Visionerna tilltog efter hand i styrka och till slut lyckades Tsangnyön verkligen rymma hemifrån, utan att någon upptäckte detta i tid och kunde stoppa honom.

Han begav sig iväg ensam och utan några tillhörigheter. Målet för hans resa var det heliga bergsområdet Tsari som ligger i sydöstra Tibet. ${ }^{80}$ Där tänkte han leva som eremit och ägna sig åt meditation. Färden gick via Lhasa, där han träffade några nunnor som också var på väg till Tsari. De slog följe och på vägen mot Tsari, i Dakpo, mötte de en berömd läkare vid namn Awo Chöje (1439-1475). Läkaren blev imponerad när han hörde hur skicklig Tsangnyön var på att recitera och bad honom stanna en tid för att recitera skrifter i hans boning. Tsangnyön tog avsked från sina färdkamrater och stannade med Awo Chöje.

Vid ett tillfälle skulle Awo Chöjes huvudsakliga lärare, Shara Rabjampa Sangye Senge (Sharawa, 1427-1470), komma på besök för att utföra buddhistiska ceremonier i Awo Chöjes residens. När den unga Tsangnyön mötte Sharawa för första gången erfor han en omvälvande andlig upplevelse. Hans sätt att förnimma världen förändrades på ett ögonblick. Som genom ett under fick han en inblick i världens och sinnets sanna natur, bortom alla de förmörkande slöjor och orenheter som dolt den för honom. Det stod därmed klart för Tsangnyön att han hade träffat sin huvudsakliga lärare och han stannade hos Sharawa i nio intensiva månader. Under denna period mottog Tsangnyön de 
rituella invigningar, muntliga instruktioner och textöverföringar som Sharawa var traditionsbärare av.

Sharawa tillhörde kagyuskolan och var känd för sin omfattande kunskap om buddhismens lära och praktiska tillämpning. ${ }^{81} \mathrm{Han}$ hade tidigare varit en lärd geshe i gelugpaskolan. Senare lämnade han munklivet och när Tsangnyön träffade honom var han en gift, tantrisk yogi. Sharawa skilde sig således en hel del från Tsangnyön som var en novismunk, förmodligen med kopplingar till sakyaskolan, när de träffades. ${ }^{82}$

Kagyuskolan som Sharawa tillhörde kom till Tibet genom översättaren Marpa (1012-1097) som reste till Indien tre gånger för att lära sig buddhismen direkt från indiska mästare. ${ }^{83}$ Den indiska buddhismen hade genomgått en långvarig utveckling när Marpa kom i kontakt med den. Under de cirka ettusenfemhundra år som då hade passerat sedan den historiska buddhan - Buddha Saàkyamuni - hade grundat buddhismen på 40o-talet före vår tideräknings början, hade en rad buddhistiska riktningar och läror utvecklats i Indien. Den grundläggande buddhismen med sitt fokus på att ta tillflykt till de tre juvelerna - den uppvaknade (buddha), läran (dharma) och församlingen (sangha) - var alltjämt grunden, men efter hand kom den så kallade stora farkosten - mahāyāna - med sitt fokus på vishet (s: prajñ̄a) och medkänsla (s: karuṇa) att alltmer dominera buddhismen i Indien och annorstädes. Helighetsidealet i buddhismen kom därmed att förändras. Det var inte längre arhaten, den ärevördiga munken, som stod högst i rang, utan bodhisattvan kom att överta dennes roll som den person som det var mest välsignelsebringande att ge gåvor till. Efter hand uppstod den tantriska buddhismen - eller vajrayāna som den också ibland kallas. Denna tradition innehåller esoteriska meditationsövningar som dess anhängare anser vara effektivare än både den ursprungliga buddhismens och mahāyānas metoder. Med hjälp av dessa tantriska metoder var det möjligt att nå fullkomnande under ett enda liv, menade man. Helighetsidealet inom den tantriska buddhismen kom att bli den fullkomnade siddhan, en gestalt som inte sällan bröt mot konventioner och uppträdde på ett udda sätt. Många av siddhorna hade valt att sluta leva som munkar, och de var ibland kritiska till munkarna, som de menade inte hade förstått den buddhistiska lärans syfte. Marpas viktigaste lärare var en sådan siddha, 
den fullkomnade mästaren Nāropa (1012-1100) ${ }^{84}$ Marpa förde vidare den esoteriska och djupsinniga undervisning som han mottagit från Nāropa och andra siddhor till sina tibetanska lärjungar. Den främsta av dessa var Milarepa.

Tsangnyön lärde sig framför allt tre utövningsmetoder av Sharawa. Den första av dessa var den så kallade hörda traditionen, som bestod av olika esoteriska muntliga instruktioner som hade förts vidare av Milarepas främsta lärjungar: Gampopa (1079-1153), Rechungpa (1085-1161) och Ngendzongpa. ${ }^{85}$ Merparten av dessa instruktioner hade traderats vidare muntligt, och Tsangnyön kom senare att systematisera och sammanställa dem i en omfattande skriftsamling. Den andra gruppen av utövningsmetoder som Tsangnyön mottog från Sharawa var Nāropas sex läror: sex olika esoteriska och avancerade utövningsmetoder som var mycket viktiga för kagyuskolans yogier. ${ }^{86}$ Det tredje centrala utövningssystemet som Tsangnyön fick lära sig var "den stora symbolen" (s: mahāmudrā), ett meditationssystem som var och fortfarande är viktigt inom kagyuskolan.$^{87}$ Dessa olika utövningsmetoder anses vara avancerade och för att kunna utöva dem måste man ha en gedigen grund som består av mer allmänna sätt att utöva buddhism, såsom tillflykten till de tre juvelerna, samt utvecklandet av det uppvaknade sinnelaget (s: bodhicitta). Den som önskar utöva dessa avancerade metoder behöver dessutom ha utvecklat vishet som bland annat innebär insikt i det egna jagets och alla fenomens tomhet (s: śūnyatā), samt ha medkänsla med alla kännande varelser. Biografierna poängterar att Tsangnyön hade denna grund när han mötte Sharawa, och att han därför kunde förstå och med stor framgång utöva ovan nämnda metoder.

När Tsangnyön förstått innebörden i de många olika instruktioner som Sharawa var traditionsbärare av, och det var tid att ge sig av, sade Sharawa följande ord till sin hängivna lärjunge:

Son, Dharmas berömmelse från Tsang, din meditationsgudomlighet är den strålande Hevajra - håll fast vid honom som din yidam. Fullkomna dina studier av tantra, såsom Hevajra Tantra. Detta kommer att vara till stor nytta i framtiden. Minns hur jag har levt och uppfört mig. Bry dig inte om denna värld. Var alltid ödmjuk. Klä dig i trasor. Strunta i mat, kläder och berömmelse. Du ska vara en son av bergen 
och klä dig i dimma. Med hjälp av ditt disciplinerade uppförande ska du låta allt det som uppstår bli en del av vägen mot uppvaknande. Var inte rädd. Bry dig inte om de åtta världsliga angelägenheterna. Res utövningens segerbaner på de stora heliga kagyuplatserna: Tsari, Lachi, Chuwar, Tise (Kailash) och de sex forten. Vägled de lyckosamma lärjungarna, de som tjänar läran, till befrielse! ${ }^{88}$

Enligt biografierna tog Tsangnyön fasta på dessa instruktioner och följde dem resten av sitt liv. Efter att ha tagit farväl från sin högt älskade lärare begav han sig till Tsari, det ursprungliga målet för den resa han påbörjat något år tidigare. I Tsari mediterade Tsangnyön med stor flit och hängivenhet.

Därefter återvände han till sin mor i Kharkha där han fortsatte att meditera i avskildhet. Tsangnyön var nu i de sena tonåren och redan en lärd munk och högt utvecklad yogi. Han hade dock ännu inte förvärvat alla de kunskaper och färdigheter som en buddhistisk traditionsbärare bör ha. Tsangnyön erinrade sig sin lärares instruktioner och kom fram till att tiden var mogen för att studera tantra.

Det nämns i texterna att Tsangnyön började studera vid ett kloster vid namn Palkor Chöde och som ligger i Gyantse, en välkänd stad i Tibet, inte långt från Kharkha. Här stannade han i drygt tre år och under denna tid studerade han framför allt de tantriska grundtexterna och deras olika kommentarer. Han vistades vid den avdelning av Palkor Chöde som specialiserade sig på Hevajra Tantra och blev snart mycket skicklig och lärd ${ }^{89}$ Tsangnyön lärde sig utföra de komplicerade ritualer som ingår i den tantriska buddhismen med dess olika melodier, frasering och rytmer. Han lärde sig spela de olika rituella instrumenten och dansa de rituella danserna som ingår i ritualerna. Dessutom lärde han sig utföra invigningsritualer, göra rituella offerkakor (torma), utföra rituella gester ( $m u d r a \bar{a})$ samt uttala de långa och invecklade mantrorna. Palkor Chöde tillhörde sakyaskolan som var den buddhistiska tradition som dominerade i den del av provinsen Tsang där Tsangnyön växte upp. Det faktum att Tsangnyön utbildade sig i ett sakyakloster visar att det rådde en öppenhet vad beträffar traditionstillhörighet vid denna tid.

När Tsangnyön hade nått fulländning i sin lärdom och bemästrade alla de kunskaper och färdigheter som en tantrisk mästare behöver 
ha, och därmed skulle kunnat skörda frukten av sina ansträngningar och få en betydelsefull position inom den monastiska hierarkin, valde han att lämna sitt kloster. Detta var, får man förmoda, både förbryllande och chockerande för de andra munkarna i Palkor Chöde och för Tsangnyöns anhöriga i Kharkha. Hur kunde någon frivilligt välja att lämna sitt kloster just när han uppnått den högsta tänkbara positionen och kunde börja åtnjuta resultaten av sina strävanden? Men berömmelse och gott anseende var inte något han eftersträvade. Sharawa hade uttryckligen uppmanat honom att inte bry sig om sådana världsliga angelägenheter. I stället önskade han förverkliga buddhismens högsta mål, det vill säga fullständigt uppvaknande, och nu var tiden mogen för att ta ytterligare ett steg mot detta mål. Biografierna poängterar att Tsangnyön hade fullbordat såväl studier som reflektion när han lämnade klostret. Det som kvarstod var att utöva det han lärt sig, vilket innebar dels att han behövde meditera, dels att han måste uppföra sig på ett sätt som gagnade den buddhistiska läran och alla kännande varelser. Han lämnade därför såväl sitt kloster som sin mor och släkt bakom sig för att "resa utövningens segerbaner på de storslagna heliga kagyuplatserna". ${ }^{90}$

Tsangnyöns sorti från munklivet var spektakulär och uppseendeväckande. När de mest framstående och mäktiga välgörarna som försåg Palkor Chöde med förnödenheter och rikedomar var på besök, och alla munkar radat upp sig i sina finaste kläder för att visa att de var väl värda fortsatt stöd, kom Tsangnyön inklampande, bärande på en kranieskål och lårbenstrumpet. Dessa rituella föremål var visserligen tillåtna i vissa sammanhang, men inte i detta. När munkarna fick te och mat i sina skålar fyllde Tsangnyön sin kranieskål och rörde om med sin lårbenstrumpet. Detta var olämpligt ur alla tänkbara synvinklar och de andra munkarna började skratta. Tsangnyön skämde på detta sätt ut sitt kloster under detta högtidliga och för klostret så viktiga besök.

Munken som hade ansvar för att upprätthålla disciplinen på klostret blev förargad och hotade att klå upp Tsangnyön som lyckades tala sig ur situationen: "I vilken sūtra eller tantra står det att man inte får ta med sig en kranieskål eller en lårbenstrumpet i munkförsamlingen?” frågade han. ${ }^{91}$ Munken som var ansvarig för disciplinen ville inte starta en diskussion med Tsangnyön som var känd för sin 
omfattande lärdom och sin skicklighet i buddhistisk debattkonst. I stället klagade han inför klostrets ledning och krävde att Tsangnyön skulle uteslutas från munkförsamlingen.

Samtidigt som detta skedde hade Tsangnyön själv börjat fundera över sin situation. Han tänkte:

Nu har jag kommit så långt som det är möjligt att komma beträffande studier och reflektion. Om jag inte uppnår erfarenhet genom att meditera så kommer kunskap och förståelse av en massa ord inte att leda mig till befrielse. Min lärare uppmanade mig också att meditera. Därför känner jag att tiden för att ge mig av och meditera vid de heliga platserna i söder nu har kommit. Dessutom är det svårt att uppnå målet som munk, och det är också en smula svårt att förena munkskapet med utövningen av de hemliga vajrayānametoderna. Jag måste offra mina tillhörigheter till munkförsamlingen och ge mig iväg. ${ }^{92}$

Därefter gav han sina munkkläder till klostret och begav sig till sin hemby strax norr om Palkor Chöde. Tillsammans med sin yngre bror, Könchog Gyaltsen, gav han sig efter några dagar återigen iväg mot Tsari för att meditera. Tsangnyön var bara drygt tjugo år gammal när han gav sig av, men han hade redan samlat på sig en hel del erfarenheter och lärdom. Han behövde dock få en djup och stabil insikt i den djupa meningen bakom alla de skrifter och meditationstekniker som han studerat och reflekterat över i Palkor Chöde. Han var ännu inte en fullt uppvaknad mästare, men nu hade tiden för utövning och förverkligande kommit.

Tsangnyön började leva som en kringvandrande yogi. Han vistades inte längre på kloster, slutade bry sig om världsliga konventioner, lät håret växa långt och började klä och uppföra sig som en tantrisk gudomlighet, en Heruka. Resten av sitt liv vandrade han runt mellan avlägset belägna meditationsplatser i södra Tibet och norra Nepal. Det tog många månader, ibland år, att genomföra den långa och farofyllda resan mellan dem. När Tsangnyön väl kommit fram till någon av platserna stannade han ofta i flera år för att meditera.

Enligt den tantriska buddhistiska traditionen finns det tjugofyra särskilt viktiga heliga platser. Utöver dessa finns åtta begravningsplatser som också anses vara mycket heliga. Vid dessa trettiotvå platser 
är det, enligt traditionen, lättare att uppnå uppvaknande. Där är de tantriska meditationsgudomligheterna särskilt närvarande. Det anses därför vara mycket gynsammt att utöva vid dem. Tibetanerna överförde denna ursprungligen indiska mytologi på sitt eget landskap och identifierade platser som ursprungligen varit belägna i Indien med platser i Tibet och Himālaya. Bland dessa trettiotvå platser återfinns Lachi, Tsari och Kailash (Tise), tre bergsområden där Tsangnyön och hans lärjungar ofta vistades. Dessa tre platser omnämns ofta i sångerna och i deras ramberättelser. Kailash identifieras med Cakrasamvaras kropp, Lachi med hans tal och Tsari med hans sinne. ${ }^{93}$

Det omtalas i biografierna hur Tsangnyön efter tre års intensiv meditation i Tsari hade ett omvälvande visionärt möte med sin meditationsgudomlighet, Hevajra som gav Tsangnyön en rituell invigning. Därefter fick Tsangnyön namnet Heruka av Hevajra. Mötet med Hevajra var den slutgiltiga bekräftelsen på att han förverkligat målet och blivit en fullkomnad mästare, en siddha. Enligt texterna var inte Tsangnyön längre bunden av världsliga konventioner utan uppfattade allting som likvärdigt - intellektualiserandet och alla uppfattningar om vad som är högt och lågt, rent och orent och så vidare hade upphört. Tsangnyön hade insett alla fenomens inneboende tomhet. Det dualistiska sättet att uppfatta världen - uppdelningen i subjekt och objekt - hade upphört och därför fanns det inte längre någon grund för självcentrerade känslor såsom hat, begär, högmod och avund. I stället genomsyrades han av uppvaknandets gränslösa vishet och medkänsla.

Det var nu dags att börja hjälpa alla kännande varelser att vakna upp ur den okunnighet och mentala bundenhet som ger upphov till tillvarons kretslopp med dess olika typer av lidanden. Tiden var mogen att sprida buddhismen till gagn för alla varelser och visa på att det är möjligt att förverkliga målet, liksom Milarepa och andra mästare tidigare hade gjort.

Tsangnyöns tillvägagångssätt var uppseendeväckande och förbryllande. Han demonstrerade sin insikt genom att trotsa såväl världsliga som religiösa konventioner. Det hände att han gick in i folksamlingar och ömsom skrattade och ömsom grät, skrek ut oförskämdheter och provocerade. Ibland förstörde han religiösa ceremonier, och han både roade och oroade sin omgivning med sitt ovanliga uppförande. 


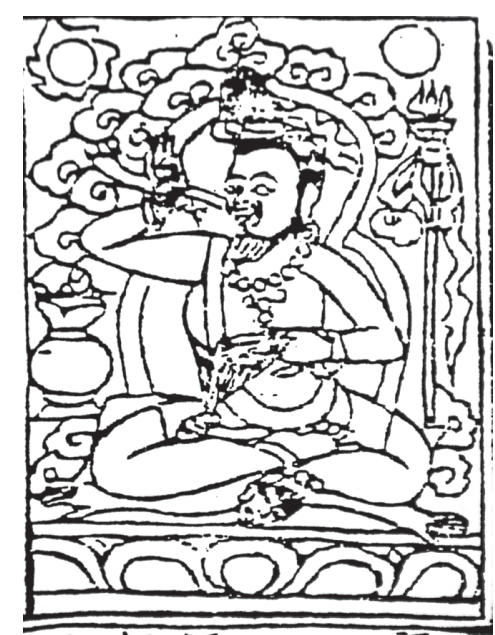

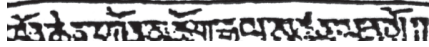

Bild 3. Tsangnyöns bror Könchog Gyaltsen (dNgos grub dpal 'bar, Dad pa'i seng ge: $1 \mathrm{~b})$.

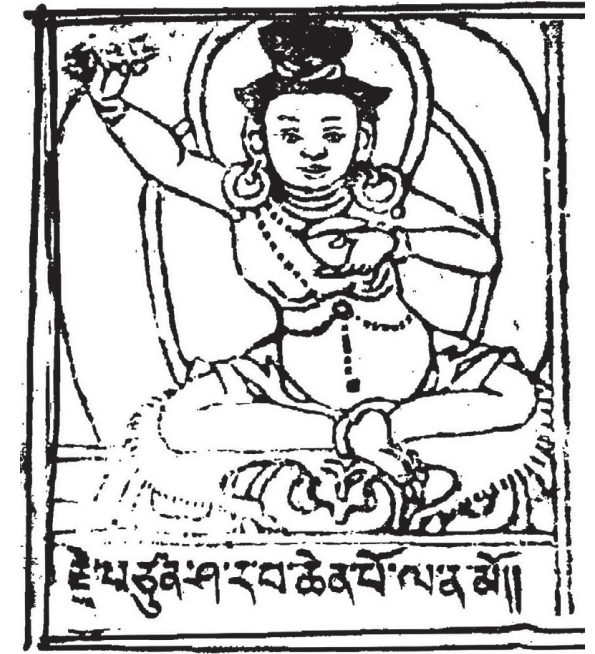

Bild 4. Tsangnyöns huvudsaklige lärare Sharawa (Zla ba rgyal mtshan, Sha ra ba'i rnam thar: $1 \mathrm{~b})$.

Det är särskilt påtagligt att han sökte upp framstående och mäktiga personer för att utmana och provocera. Vid ett flertal tillfällen gick han fram till lokala kungar när de satt på sina höga säten med sina ministrar och anhängare runt om sig. ${ }^{94}$ Tsangnyön gick helt fräckt förbi vakterna som skulle hindra obehöriga att störa den kungliga sammankomsten, tog bägaren som stod framför kungen och drack upp dess innehåll. Det är värt att notera att reaktionen han mötte varierade. I vissa fall blev kungarna hängivna och imponerade när de såg honom - de uppfattade hans uppförande som ett tecken på att han var en stor yogi - men $i$ andra fall blev de förödmjukade och arga.

Vid ett tillfälle när Tsangnyön besökte en stūpa i Tsetang blev han angripen av en grupp berusade människor. Fast beslutna att slå ihjäl den galna yogin, som i deras ögon besudlade stūpan med sin närvaro, angrep de Tsangnyön. Det visade sig dock vara stört omöjligt att döda honom. När hans uttröttade angripare upptäckte att en strid ström av tårar rann nedför Tsangnyöns kinder undrade de om han kanske ändå kände smärta; kanske höll de på att besegra honom, trots allt. Smärtan han kände var dock inte av det vanliga slaget. Han grät av 
medkänsla gentemot de som angrep honom. "Hur kan de slösa bort sina dyrbara människoliv med sådana aggressiva handlingar?" undrade Tsangnyön. ${ }^{95}$

Förundrade över Tsangnyöns mirakulösa förmågor och djupa medkänsla började hans angripare ångra sig. De insåg att han var en bodhisattva, en osjälvisk person som var på väg att bli en uppvaknad, en blivande buddha, och de avslutade sin attack.

Enligt biografierna ägde Tsangnyöns till synes galna uppförande rum under en begränsad period. Denna period varade från och med att han lämnat klostret och cirka tio år framåt. Från tiden därefter, från och med att Tsangnyön var drygt trettio år gammal och fram till hans bortgång när han var femtiofem, återges inte särskilt många utmanande och normöverskridande handlingar i texterna.

När Tsangnyön var i tjugoåttaårsåldern började han undervisa andra, och i och med detta fick han egna lärjungar. Det var också under denna period han började förmedla sina insikter vidare till andra via sånger. Tsangnyön var inte längre en buddhistisk utövare som strävade mot fullkomning, utan en fullkomnad mästare, med kapacitet att vägleda och hjälpa andra.

Han nöjde sig dock inte med att undervisa och sjunga sånger till dem han mötte, utan började också sammanställa sina insikter i texter som han sedan tryckte upp. Genom dessa texter kom han att påverka inte bara sina lärjungar, utan även många andra. Några av de texter han sammanställde kom att bli litterära klassiker och i dag framstår Tsangnyön som en av Tibets främsta författare och diktare. Tsangnyön var en central och viktig aktör i den boktryckningskultur som utvecklades i Tibet under 1400-talet. Denna nya teknik gjorde det möjligt att sprida kunskap på ett helt annat sätt än tidigare och kom att revolutionera och förändra det tibetanska samhället och religionen..$^{96}$

Efter en viss tvekan bestämde sig Tsangnyön, när han var i trettiofemårsåldern, för att sammanställa och trycka en biografi över Milarepa samt en samling av Milarepas sånger. Detta var ett svårt, kostsamt och tidskrävande arbete. Biografierna om Tsangnyön beskriver vilka tankar som rörde sig i hans huvud innan han sammanställde dessa båda texter: 
Vilka djupa och omfattande läror och vilka muntliga instruktioner ska vi lära ut till dem som har de rätta förutsättningarna, så att de uppnår befrielse? Alla människor - från kungen, ministrarna och ledarna som är stolta över sin höga position, till de enkla människorna och alla däremellan - har lovat att de ska förvärva förtjänster. Men de har inte tid att handla på ett sätt som överensstämmer med den heliga läran. Även om vi skulle inspirera dem till att utöva läran, och även om de hade tid, så skulle de inte kunna utöva den djupa essensen. De skulle endast följa ordens mening, föränderlig som en bubbla.

Hur ska vi lära dem den högsta metoden - juvelen som uppfyller alla önskningar och som leder till buddhas nivå i ett enda liv? Hur ska vi väcka den goda potentialen hos dem som känner stolthet över att de har uppnått en geshetitel?

Om den vördade Milarepas livshistoria skulle göras tillgänglig, skulle den bli till ett exempel som visar dem som strävar efter detta livs sinnesnjutningar värdet av ansträngning och förmåga att uthärda lidanden. För dem som tvivlar på att det går att uppnå uppvaknandet i ett enda liv och som inte har tid för meditation, skulle en sådan biografi bli ett perfekt exempel som visar att det är möjligt att nå uppvaknande. Och de skulle utveckla förtroende för den heliga lärans yttersta mening.

De som har de bästa förutsättningarna skulle uppnå befrielse under ett enda liv, och de med medelgoda förutsättningar, även de som saknar inre erfarenheter, skulle utveckla tro och hängivenhet gentemot dem som utövar. De skulle därigenom skapa bra förutsättningar, och på grund av deras helt rena önskningar skulle deras sinnen bli inställda på utövning i nästa liv. Detta skulle göra att även de uppnår befrielse. Till och med de som har de allra sämsta förutsättningarna skulle ge upp felaktiga uppfattningar och utveckla en djup tro. Därpå skulle de bli personer för vilka tillvarons kretslopp har ett slut. Vad underbart detta vore. ${ }^{97}$

Efter att ha beslutat sig för att sammanställa biografin över Milarepa och Milarepas sångsamling, samlade Tsangnyön och hans lärjungar ihop de berättelser om Milarepa och de sånger av honom som fanns spridda i Tibet med omnejd. Det var en tidskrävande och svår uppgift eftersom detta material inte hade systematiserats ordentligt tidigare. Därefter anlitade han några av de främsta korrekturläsarna, kalligraferna och träblockssnidarna i södra Tibet. Genom att låta framställa träblock som användes för att trycka upp dessa bägge verk kunde 
de spridas på ett effektivt sätt, vilket bidrog till att göra biografin om Milarepa och sångsamlingen kända inte bara i Tibet utan även i angränsande områden.

Parallellt med denna litterära verksamhet började Tsangnyön undervisa och utföra buddhistiska invigningsritualer, och efter hand fick han alltfler lärjungar. Det var en brokig skara som samlades kring den galna yogin. Bland hans lärjungar återfanns kungar och drottningar, munkar och nunnor, manliga och kvinnliga yogier, samt lekfolk. Några av dessa fick en särskilt stor betydelse inom Tsangnyöns tradition och blev själva erkända mästare med stort inflytande. Tsangnyöns kvinnliga partner, lärjunge och följeslagare, Kuntu Sangmo (1464-1549); Tsangnyöns yngsta lärjunge, yogin Götsangrepa (14821559); den lärda sakyamunken Ngödrub Pembar (1456-1527); och den högt uppsatta munken Lhatsun Rinchen Namgyel (1473-1557), som var av kunglig börd, förtjänar ett särskilt omnämnande. ${ }^{98}$

Eftersom Kuntu Sangmo kom att få en särskilt central roll i traditionen, och eftersom det var genom hennes försorg som Tsangnyöns sångsamling sammanställdes och trycktes, kan det vara på sin plats att säga några ord om henne, innan vi återgår till Tsangnyöns livsberättelse.

Kuntu Sangmos livshistoria påminner om många andra buddhistiska mästares livshistorier, men skiljer sig i vissa avseenden. Dessa skillnader beror framför allt på att hon var kvinna. Det är sällsynt med kvinnliga mästare i buddhismen, och biografiska uppgifter om de få kvinnor som har funnits är vanligtvis knapphändiga. ${ }^{99}$ Ett återkommande tema som ingår i de flesta av de fåtaliga biografier över kvinnliga mästares liv som i dag finns tillgängliga, visar att det var svårt för en tibetansk kvinna att ägna sig helhjärtat åt buddhistisk utövning. Ofta måste kvinnor kämpa hårdare än män för att få tillåtelse och möjlighet att lämna det världsliga livet. Inte sällan var kvinnor som ville viga sitt liv åt buddhismen tvungna att gifta sig och skaffa barn, vilket gjorde det svårt för dem att leva det asketiska liv som de själva önskade. De kvinnor som ändå blev nunnor eller yogier hade svårare att få stöd och respekt än män i motsvarande belägenhet. Fastän denna situation håller på att förändras är det fortfarande ofta svårare för kvinnor att lämna det världsliga livet och helt ägna sig åt buddhistisk praktik, än vad det är för män. Med tanke på detta är 


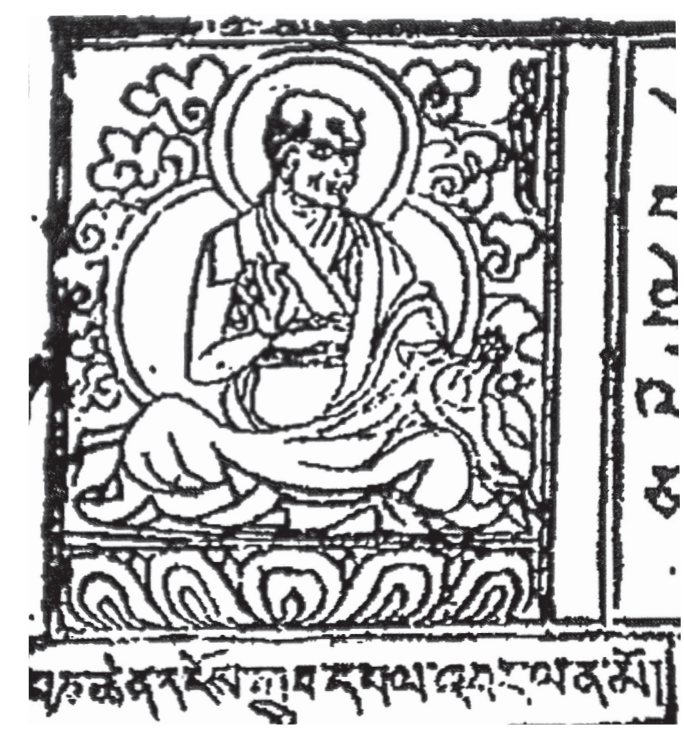

Bild 5. Den lärda munken Ngödrub Pembar (Byams pa lha btsun grags pa, dNgos grub dpal 'bar gyi rnam thar: 383 ).

det anmärkningsvärt att det faktiskt fanns flera framstående kvinnor i den tibetanska buddhismen för hundratals år sedan. Två av traditionsbärarna i Tsangnyöns tradition - den hörda traditionen - var kvinnor: Machik Ongjo Rema (född under 110o-talet) och Machik Trulshig Kunden Rema (född på 1300-talet). ${ }^{100}$ Vi vet mycket lite om dessa bägge kvinnliga mästare, liksom vi vet lite om många av de andra traditionsbärarna inom denna obskyra överföringstradition. Men det faktum att en kvinna kunde inneha rollen som den högsta traditionsbäraren i den hörda traditionen visar att kvinnor fanns, och att de kunde ha betydelsefulla positioner, åtminstone i just denna tradition. Kuntu Sangmo är ytterligare ett exempel på att det fanns betydelsefulla kvinnliga mästare i den tibetanska buddhismen, och tack vara en utförlig biografi över hennes liv finns det en hel del uppgifter om henne. ${ }^{101}$

Kuntu Sangmo var född i en högt uppsatt familj och det sägs att hon redan som barn utmärkte sig genom sin medkänsla och visdom. När hon blev äldre ville hon endast ägna sig åt buddhistisk utövning, 
men tvingades mot sin vilja att gifta sig med en nyingmalama. Detta gjorde henne mycket bedrövad och när hennes make dog efter endast några månaders äktenskap såg hon detta som en möjlighet att få ägna sig åt buddhistisk praktik på heltid. Hennes avlidna mans anhöriga hade dock andra planer och var fast beslutna att Kuntu Sangmo skulle stanna kvar hos dem. Eftersom även hennes egen familj ogillade hennes planer på att lämna det världsliga livet, fann Kuntu Sangmo till slut ingen annan utväg än att rymma. Tillsammans med en medhjälpare begav hon sig till ett kloster vid namn Palmo Chöding där hon mottog novislöften från klostrets abbot. Kuntu Sangmo stannade på klostret och studerade Chogle Namgyels (1376-1451) samt den kvinnliga yogin Machik Labdröns (1055-1149) läror. Palmo Chöding tillhörde bodongskolan, en tradition som fortfarande finns kvar i Tibet men som inte är så känd i väst. Det sägs att Kuntu Sangmo uppnådde medkänsla och avståndstagande från tillvarons kretslopp med hjälp av dessa läror, men det påpekas också att lärorna inte resulterade i någon djupare insikt.

När Kuntu Sangmo vistades i Palmo Chöding hörde hon talas om Tsangnyön för första gången. Det nämns att hon överväldigades av en i det närmaste "outhärdligt stark hängivenhet när hon hörde hans namn nämnas". ${ }^{102}$ Kuntu Sangmo bestämde sig omedelbart för att söka upp den galna yogin som då befann sig i Kristallgrottan i Nedum Shelpuk i södra Latö. ${ }^{103}$ Där höll han på att färdigställa tryckblocken till biografin över Milarepa, och eftersom biografin trycktes år 1488 och sammanställandet av texten tog ett par år så är det rimligt att tänka sig att Kuntu Sangmo mötte Tsangnyön för första gången cirka 1487, då hon var tjugotre år gammal och han var trettiofem.

Natten innan Kuntu Sangmo anlände drömde en av de hundra kvinnliga utövare som vistades tillsammans med Tsangnyön, att en kvinna smyckad med benornament och klädd i silke kom för att möta Tsangnyön. Tsangnyön sade att kvinnan i drömmen hade alla tecken på att vara en uppvaknad kvinna, en så kallad ḍākinī, och han förutsade att hon skulle anlända inom kort. "Denna kvinna saknar like och kommer att sprida läran vidare", tillade Tsangnyön. ${ }^{104}$

Samma dag anlände Kuntu Sangmo tillsammans med sin medhjälpare. Hon offrade alla sina tillhörigheter och smycken till Tsangnyön, och han gav henne en rituell invigning samt instruktioner i 
mahāmudrā. Genom dessa instruktioner uppnådde Kuntu Sangmo genast den insikt som undervisningen hon mottagit tidigare inte hade gett upphov till.

Det nämns i biografin att hennes välbärgade familj inte ville bidra med mat och andra förnödenheter när hon praktiserade buddhismen under Tsangnyöns vägledning. Förbittrade över att hon inte lyssnat varken till dem eller till den familj som hon blivit ingift $i$, lät de henne klara sig på egen hand. Biografin förtäljer också att Tsangnyön använde dessa omständigheter till att rena Kuntu Sangmo från de orenheter som alltjämt fanns kvar i hennes sinne och som hindrade henne från att uppnå det slutgiltiga uppvaknandet. Tsangnyön ville också testa hennes hängivenhet och se om hon hade förmåga att anstränga sig. Han gav henne därför inte heller något materiellt stöd, utan lät Kuntu Sangmo utöva meditation utan tillgång till mat och förnödenheter. Detta avskräckte dock inte denna extraordinära kvinna. Med stor flit och hängivenhet studerade hon de läror och utövningsmetoder som Tsangnyön förmedlade till henne. Efter hand lärde sig Kuntu Sangmo alla de centrala utövningsmetoderna och lärorna som Tsangnyön var traditionsbärare av, och efter att ha utövat och studerat dessa läror på ett felfritt sätt, blev hon själv en erkänd och respekterad mästare. Tsangnyöns andra lärjungar hyste stor vördnad för henne och flera blev också lärjungar till henne.

Efter att ha träffat Kuntu Sangmo fortsatte Tsangnyön att resa runt mellan heliga platser, ägna sig åt meditation, undervisa, ge rituella invigningar, vägleda sina lärjungar och sammanställa texter. År 1504 genomförde han den handling som hans lärjungar verkade ha uppfattat som den allra mest betydelsefulla: en grundlig renovering av den välkända Svayambhūstūpan i Nepal. ${ }^{105}$ Tsangnyön både finansierade och organiserade detta omfattande, kostsamma och komplicerade projekt. Det faktum att kungen av Katmandu, Ratnamalla, bad Tsangnyön åta sig denna prestigefyllda uppgift vittnar både om vilket högt anseende Tsangnyön hade fått och om vilket omfattande kontaktnät av välgörare han hade skaffat sig.

När Tsangnyön återvände till Tibet efter att ha renoverat stūpan var även de som tidigare tvivlat på hans kvaliteter övertygade om att han var en genuin mästare, en siddha. Var helst han färdades samlades människor som ville beskåda denna extraordinära yogi som 


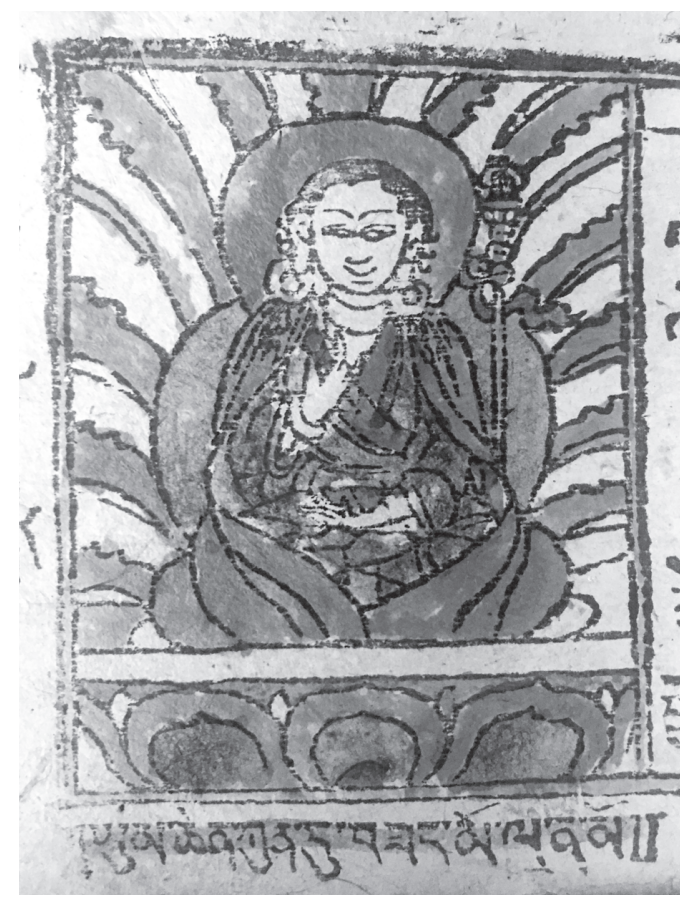

Bild 6. Kuntu Sangmo (gTsang smyon he ru ka, gTsang pa he ru ka'i mgur 'bum: 28a).

utfört så många enastående ting. Det sägs att så många människor samlades att det var svårt att få en glimt av den galna yogin och än svårare att falla till marken i vördnad framför honom på grund av trängseln. Den mest framträdande andliga auktoriteten under denna period, den sjunde Karmapa (1454-1506) skrev ett hyllningsbrev, ${ }^{106}$ och Tibets högsta världsliga ledare, Dönyö Dorje (1462-1512), blev hans hängivna lärjunge och välgörare. Tsangnyön var nu drygt femtio år gammal och hade på många sätt nått höjdpunkten i sin karriär.

Tsangnyöns litterära produktion fortsatte in i det sista. När han återvänt från Nepal sammanställde han en biografi över Marpa. ${ }^{107}$ Denna blev mycket omtyckt och anses, precis som biografin om Milarepa, vara ett litterärt mästerverk, om än inte lika välkänt som biografin över Milarepa. Tsangnyön sammanställde därefter sitt mest omfattande litterära verk, en samling med kagyuskolans esoteriska 
läror, de så kallade hörda traditionerna. När han fullbordat detta arbete sade han:

Jag har helt ägnat mig åt den hörda traditionen och åt den vördade Milas livshistoria. Nu, när den hörda traditionens texter är sammanställda, är min livstid också fullkomnad. Jag, en asket, har gjort en hel del arbete för Buddhas lära. Det enda jag ångrar är att jag inte lyckats färdigställa en kopia skriven i guld av den hörda traditionens texter, som jag hade för avsikt att göra, samt att jag inte vitmålat Svayambhūstūpan ytterligare en gång. Jag är redo att dö redan i dag och jag tror inte att jag kommer att leva särskilt länge. ${ }^{108}$

Därefter, då Tsangnyön var femtiofyra år gammal 1505, började hans hälsa successivt försämras, men han lät inte sin dåliga hälsa stoppa honom, utan fortsatte att resa. Under sin färd undervisade han och gav rituella invigningar till ett stort antal människor. När han kom till Lhasa offrade han ljus och bad önskeböner inför den för tibetaner så heliga Jowostatyn i Jokangtemplet. Trots sin bräckliga hälsa fortsatte han att undervisa alla de som sökte upp honom. Hans lärjungar försökte övertala honom att sluta undervisa och tänka på sin hälsa, men Tsangnyön svarade dem med följande ord: "Om jag dör för lärans och de kännande varelsernas skull så är det bra. Jag kan inte ge upp läran." ${ }^{109}$ Han undervisade alla som önskade och etablerade dem därmed på vägen som leder till befrielse.

Till slut var han så svag att lärjungarna fick bära honom i en bärstol, och det blev alltmer uppenbart att han inte hade lång tid kvar att leva. Det fanns inte längre tid att färdas till Tsangnyöns favorittillhåll, Tsari. I stället begav han sig med följe till Rechungpuk, strax söder om Tsetang. Milarepas lärjunge Rechungpa hade mediterat i denna eremitboning, och Tsangnyön uppfattade det som lyckosamt att färdas till denna heliga plats. "Låt oss gå dit nu. Fadern ska dö i sonens hus", sade han. ${ }^{110}$

När Tsangnyön anlänt till Rechungpuk uppstod vackra molnformationer, och hans lärjungar hade drömmar som förutspådde hans stundande bortgång. Det rådde inte längre några tvivel om att Tsangnyön snart skulle lämna denna värld. När hans närmaste 
lärjungar förstod detta bad de Tsangnyön ge dem några sista råd. Tsangnyön yttrade då dessa ord:

Nu när min sista vila är förestående och jag gjort många förberedelser inför dödsögonblicket, så är inget annat nödvändigt. Om ni lyssnar till mina ord så ägna era liv åt att utöva. Att göra detta är att fullborda, inte bara mina önskningar, utan även alla buddhors och bodhisattvors. Munkar, lärjungar och välgörare, ni har mött Milarepa i denna mörka tidsålder, så ni har god karma och ni är lyckligt lottade. Läs regelbundet Milas berättelse och ägna era liv åt utövning! I Milas livshistoria kommer ni att höra min verkliga röst och ni kommer att bli omhändertagna! ${ }^{111}$

Därefter upptäckte läkaren som vårdade Tsangnyön att han inte kunde känna Tsangnyöns puls. Han förstod att Tsangnyön snart skulle dö och började gråta. Tsangnyön tröstade honom med följande ord: "Det finns ingen anledning att vara ledsen över min död. Jag visste redan att döden skulle komma och har ägnat hela mitt liv åt att utöva i de tre heliga bergsområdena. Men det är ditt sätt att reagera. Medan vanliga människor blir rädda, upplever inte yogin någon skillnad mellan liv och död." 12

När den klarblå himlen började fyllas med vackra mångfärgade regnbågar och moln förstod de många människor som samlats $\mathrm{i}$ Rechungpuk att deras böner för Tsangnyöns hälsa varit verkningslösa. ${ }^{113}$ Insikten om att deras högt älskade lama, den galna yogin från Tsang, var på väg att lämna dem gjorde de församlade ledsna, rädda och oroliga.

Tsangnyön uppmanade sina lärjungar att klä honom i nya kläder och hjälpa honom att sätta sig i meditationsställning. Den femtonde dagen i den femte månaden år 1507 lämnade Tsangnyön denna värld. Genom sin död visade han de församlade förgänglighetens ofrånkomlighet. När han dog var det, enligt Ngödrub Pembar, som om "lärans sol gick ner i Tibet och det blev skymning". ${ }^{114}$ 


\section{Sångsamlingen sammanställs och trycks}

Efter Tsangnyöns kremering utförde hans lärjungar allehanda ceremonier för att vörda och minnas "dåren från Tsang". ${ }^{115}$ De visade sin vördnad för Tsangnyöns kropp genom att framställa hundratals statyer och målningar som föreställde honom. De visade sin vördnad för hans tal genom att sammanställa och trycka en biografi om honom och hans sångsamling, och de visade sin aktning för hans sinne genom att utöva de läror han förmedlat vidare till dem. Vissa av lärjungarna tillbringade resten av sina liv i avskildhet för att förverkliga den djupa innebörden i dessa läror.

Lärjungarnas vördnadsbetygelser till Tsangnyöns tal är av särskilt intresse i detta sammanhang. Det nämns i den biografi om Tsangnyön som skrevs av Götsangrepa att hans andliga gemål, Kuntu Sangmo, tryckte upp en biografi om Tsangnyön som var författad av Ngödrub Pembar samt en sångsamling vid detta tillfälle. ${ }^{116}$ De sista sidorna i dessa tibetanska blocktryck avslöjar att nedtecknandet skedde året efter Tsangnyöns bortgång, år 1508, i ett kloster vid namn Samten Ling som låg i södra Latö, en plats i närheten av det heliga berget Tsibri, nordväst om Lachi. ${ }^{117}$ Enligt kolofonen i sångsamlingen var det

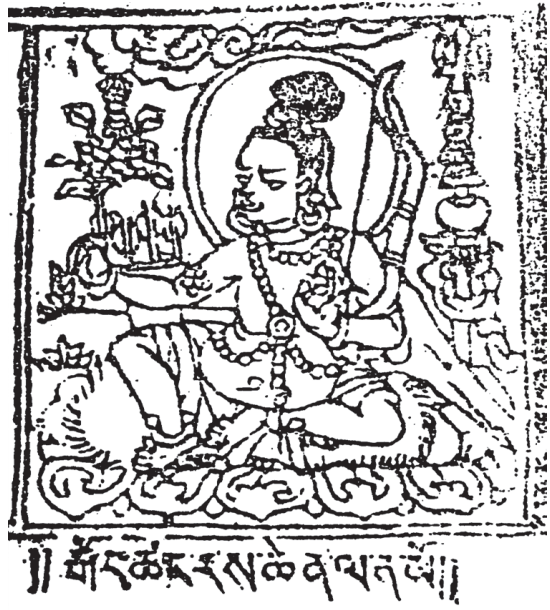

Bild 7. Götsangrepa (rGod tshang ras pa, Nyi ma'i snying po: 287).

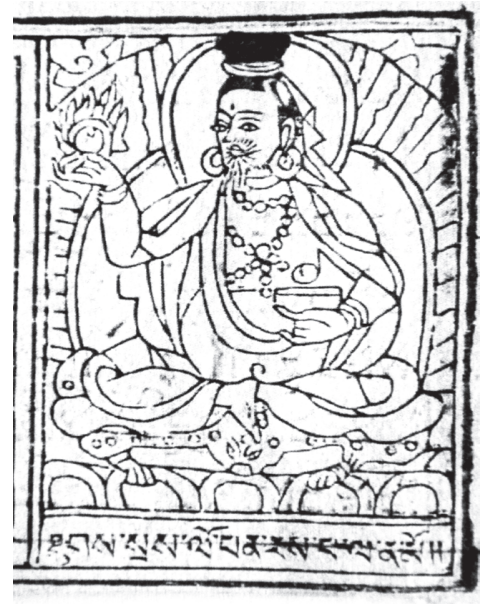

Bild 8. Lopen Jampel Chöla ('Jam dpal chos lha, Yang dgon gyi rnam thar: 75b). 
yogin Götsangrepa som satte samman merparten av sångsamlingen. Kuntu Sangmo hade en särskilt viktig roll eftersom det var hon som tog initiativet till den och bekostade den.

När sångsamlingen och biografin var färdigskrivna redigerades texterna av en annan av Tsangnyöns närmaste lärjungar, Lopen Jampel Chöla (född 1478). Därefter anlitades en kalligraf från Menkab samt en träsnidare från Zurtso, två regioner som ligger relativt nära Samten Ling där texterna sammanställts. Kalligrafen skrev ner texterna med vackra tryckbokstäver som träsnidaren karvade in i träblock. Dessa träblock användes sedan för att framställa kopior av texterna som distribuerades till hängivna lärjungar för att bevara minnet av Tsangnyön och låta hans "uppvaknade tal" gagna även de som inte själva haft förmånen att lyssna till det direkt. Sångsamlingen och biografin gavs ut som fristående delar av en större volym där även en text om sånger som Tsangnyön författat och en översikt över sångerna skriven av Götsangrepa förmodligen ingick. ${ }^{118}$ När dessa texter var färdiga var ceremonierna kring Tsangnyöns bortgång fullbordade. 